Article

\title{
Synthesis of PNVP-Based Copolymers with Tunable Thermosensitivity by Sequential Reversible Addition-Fragmentation Chain Transfer Copolymerization and Ring-Opening Polymerization
}

\author{
Yi-Shen Huang ${ }^{1}$, Jem-Kun Chen ${ }^{2}$, Tao Chen ${ }^{3}$ and Chih-Feng Huang ${ }^{1, *}$ \\ 1 Department of Chemical Engineering, National Chung Hsing University, 250 Kuo Kuang Road, \\ Taichung 40227, Taiwan; yishen617@gmail.com \\ 2 Department of Materials Science and Engineering, National Taiwan University of Science and Technology, \\ 43, Sec. 4, Keelung Road, Taipei 10607, Taiwan; jkchen@mail.ntust.edu.tw \\ 3 Department of Polymer and Composite, Ningbo Institute of Materials Technology and Engineering Chinese \\ Academy of Sciences, Zhongguan West Road 1219, Ningbo 315201, China; tao.chen@nimte.ac.cn \\ * Correspondence: HuangCF@dragon.nchu.edu.tw; Tel.: +886-4-2284-0510
}

Academic Editors: Jinlian Hu and Rui Xiao

Received: 18 May 2017; Accepted: 14 June 2017; Published: 18 June 2017

\begin{abstract}
Through the reversible addition-fragmentation chain transfer (RAFT) copolymerization of 3-ethyl-1-vinyl-2-pyrrolidone ( $\left.\mathrm{C}_{2} \mathrm{NVP}\right)$ and $\mathrm{N}$-vinylpyrrolidone (NVP), a series of well-defined $\mathrm{P}\left(\mathrm{C}_{2} \mathrm{NVP}-\mathrm{co}-\mathrm{NVP}\right)$ copolymers were synthesized $\left(M_{\mathrm{n}}=\right.$ ca. 8000 to 16,000 and $\left.M_{\mathrm{w}} / M_{\mathrm{n}}<1.5\right)$ by using a difunctional chain transfer agent, S-(1-methyl-4-hydroxyethyl acetate) O-ethyl xanthate (MHEX). Copolymerizing kinetics and different monomer ratio in feeds were conducted to study the apparent monomer reaction rate and reactivity ratios of NVP and $\mathrm{C}_{2} \mathrm{NVP}$, which indicated similar reaction rates and predominantly ideal random copolymers for the two monomers. The $T_{\mathrm{g}} \mathrm{S}$ of the obtaining $\mathrm{P}\left(\mathrm{C}_{2} \mathrm{NVP}-\mathrm{co}-\mathrm{NVP}\right)$ copolymers significantly corresponded to not only molecular weights MWs but also copolymer compositions. These copolymers presented characteristic lower critical solution temperatures (LCST) behavior. We then studied the cloud points (CPs) of the copolymers with varying MWs and compositions. With different MWs, the CPs were linearly decreased from ca. 51 to $45^{\circ} \mathrm{C}$. With different compositions, the CPs of the copolymers decreased from ca. 48 to $29{ }^{\circ} \mathrm{C}$ with $\mathrm{C}_{2} \mathrm{NVP}$ content (i.e., from 60.8 to $89.9 \mathrm{~mol} \%$ ). Fitting the $\mathrm{CPs}$ by the theoretical equation, the result illustrated that the introduction of more hydrophobic units of $\mathrm{C}_{2} \mathrm{NVP}$ suppressed the hydrophilic interaction between the polymer chain and water. We then successfully proceeded the chain extension through the ring-opening polymerization (ROP) of $\varepsilon$-caprolactone (CL) to the synthesis of a novel $\mathrm{P}\left(\mathrm{C}_{2} \mathrm{NVP}-\mathrm{co}-\mathrm{NVP}\right)-b$-PCL amphiphilic block copolymer $\left(M_{\mathrm{n}, \mathrm{NMR}}=14,730\right.$ and $M_{\mathrm{w}} / M_{\mathrm{n}}=1.59$ ). The critical micelle concentration (CMC) of the block copolymer had a value of ca. $1.46 \times 10^{-4} \mathrm{~g} / \mathrm{L}$. The block copolymer micelle was traced by dynamic light scattering (DLS), obtaining thermosensitive behaviors with a particle size of ca. $240 \mathrm{~nm}$ at $25^{\circ} \mathrm{C}$ and ca. $140 \mathrm{~nm}$ at $55^{\circ} \mathrm{C}$, respectively.
\end{abstract}

Keywords: poly( $N$-vinylpyrrolidone); RAFT copolymerization; ring-opening polymerization; thermosensitive block copolymer; poly(E-caprolactone)

\section{Introduction}

Thermoresponsive polymers that exhibit lower critical solution temperatures (LCST) in aqueous solution are among the most important water-soluble polymers. These polymers have found versatile applications in various fields, such as catalysis, intelligent drug delivery, and tissue 
engineering [1-5]. A key feature of these polymers is a reversible phase transition in an aqueous solution, resulting from a reversible change of polymer conformation at a certain temperature (i.e., cloud point $(\mathrm{CP})$ ). In general, this phenomenon is based on the diminishing entropy with increasing temperature caused by the immobilization of the solvent molecules on the surface of the dispersed polymer chain. Based on the side group structures, these polymers can be mainly categorized into four classes: amide [6-8], ether [9,10], oxazoline [11,12], and amino acrylate [13,14]. For the rational design of a new type of thermoresponsive polymer, a key is to reveal its significant and tunable phase transition property. Poly(N-isopropyl acrylamide) (PNIPAM) is the most widely studied amide-type thermoresponsive polymer, which possesses a secondary amide group with a hydrophobic isopropyl group in the side chain. In an aqueous solution, PNIPAM performs a sharp and reversible phase transition at a temperature that is close to our body temperature. The CPs of homopolymers containing an amide side group, such as poly(N-vinylcaprolactam) (PNVCL) and poly( $N, N$-diethylacrylamide) (PDEA), generally display significant and simple thermosensitive behaviors. The Cai group synthesized a series of pyrrolidone-based (co)polymers, such as poly[N-(2-methacryloyloxyethyl)pyrrolidone] (PNMEP), poly[N-(3-acryloyloxypropyl)pyrrolidone] (PNAPP), and poly[N-(3-methacryloyloxypropyl)-pyrrolidone] (PNMPP) $[15,16]$. They interestingly demonstrated that the fully hydrated state of the polymers in $\mathrm{D}_{2} \mathrm{O}$ had a phase transition occur at the cloud point, and that further heating leads to dehydration and separation from the $\mathrm{D}_{2} \mathrm{O}$. The Ritter and Li groups found that ethyl-substituted $\mathrm{N}$-vinylpyrrolidone (NVP) at the 3-position (i.e., $\mathrm{C}_{2} \mathrm{NVP}$ ) featured a thermoresponsive polymer (i.e., $\mathrm{PC}_{2} \mathrm{NVP}$ ) with a significant $\mathrm{CP}$ in water. The $\mathrm{CP}$ of $\mathrm{PC}_{2} \mathrm{NVP}$ is around $25{ }^{\circ} \mathrm{C}[8,17-19]$, which can be adjusted by free radical copolymerization with NVP [19]. The exploration of the $\mathrm{P}\left(\mathrm{C}_{2} \mathrm{NVP}-\mathrm{co}-\mathrm{NVP}\right)$ copolymers' properties has not been addressed. Thus, tuning thermosensitive behaviors is also an important and practical issue. Generally, control over the LCST of thermoresponsive polymers has been achieved by manipulating either the chemical factors, such as polymer structure, composition, chain-end groups, and polymer molecular weights, or the physical factors, such as additives and organic solvents [20-23]. Furthermore, the relationship between CP and composition was discussed by the theoretical Kwei equation [24].

In the past few decades, significant efforts have been devoted to the development of living polymerizations, including reversible-deactivation radical polymerizations (RDRPs) [25], living polycondensations [26-29], ring-opening polymerizations (ROPs) [30], anionic [31,32]/cationic [33] polymerizations, and ring-opening metathesis polymerizations (ROMPs) [34]. These methods provide mighty tools for the preparation of unprecedented nanomaterials $[35,36]$. Through free radical chemistry, RDRPs render innovative polymeric materials from a variety of monomers, leading to excellent control over chain functionality, molecular weight (MW), and molecular weight distribution (MWD). The most widely studied RDRP systems include nitroxide-mediated radical polymerization (NMRP) [37], reversible addition-fragmentation transfer (RAFT) polymerization [38], and atom transfer radical polymerization (ATRP) [39,40]. In addition, some other RDRP systems have been also reported [41-44]. For the so-called "more reactive monomers" (MAMs), the propagating radicals can be stabilized via the resonance or inductive effect. The MAMs can be generally proceeded to control polymerization through an ATRP mechanism [45-47]. Although there has been significant progress and good design in the ATRP catalytic systems [48-50], challenges still remain for controlling the polymerizations of "less reactive monomers" (LAMs) such as NVP and NVCL. Thus, combinations of two living polymerization mechanisms (herein: RAFT polymerization and ROP) by a dual functional initiator could provide a facile route to the synthesis of new well-defined thermosensitive (co)polymers.

As shown in Scheme 1, we first synthesize a series of $\mathrm{P}\left(\mathrm{C}_{2} \mathrm{NVP}-\mathrm{co}-\mathrm{NVP}\right)$ copolymers through RAFT polymerization with the dual functional MHEX chain transfer agent. Our attempt is to obtain well-defined PNVP-based copolymers (i.e., C1-C6 copolymers) with tunable thermosensitivity and chain-end functionality. Detailed studies of kinetic characterization during RAFT copolymerization, the thermal properties of the copolymers in solid-sate, and the cloud point $(\mathrm{CP})$ phenomena of the copolymers in water were discussed. We further proceeded the chain extension of 
$\mathrm{P}\left(\mathrm{C}_{2} \mathrm{NVP}\right.$-co-NVP)-OH through the ROP of $\varepsilon$-caprolactone $(\mathrm{CL})$ to the synthesis of a novel $\mathrm{P}\left(\mathrm{C}_{2} \mathrm{NVP}-c o-\mathrm{NVP}\right)-b$-PCL amphiphilic block copolymer. Eventually, block copolymer micelle was prepared and traced by dynamic light scattering (DLS) to demonstrate the thermosensitive behaviors of the novel $\mathrm{P}\left(\mathrm{C}_{2} \mathrm{NVP}-c o-\mathrm{NVP}\right)-b$-PCL amphiphilic block copolymer.

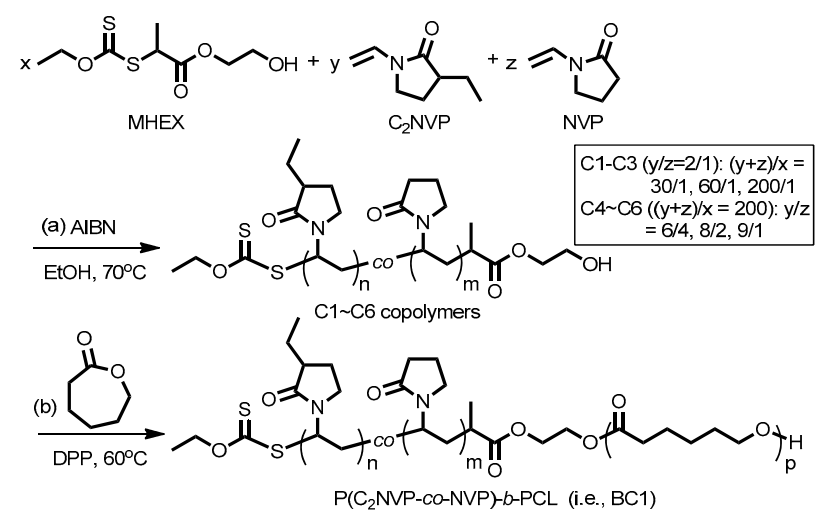

Scheme 1. (a) reversible addition-fragmentation transfer (RAFT) copolymerization of $\mathrm{N}$-vinylpyrrolidone (NVP) and 3-ethyl-1-vinyl-2-pyrrolidone $\left(\mathrm{C}_{2} \mathrm{NVP}\right)$ and (b) ring-opening polymerization (ROP) of $\varepsilon$-caprolactone (CL).

\section{Materials and Methods}

\subsection{Materials}

Ethylene glycol (EG, 99\%), pyridine (99\%), 2-bromopropanoyl bromide (98\%), potassium ethyl xanthate (97\%), 1-bromoethane (98\%), azobisisobutyronitrile (AIBN, 99\%), $2.0 \mathrm{M}$ lithium diisopropylamide (LDA) in tetrahydrofuran (THF), diphenyl phosphate (DPP, 97\%), and anhydrous magnesium sulfate $\left(\mathrm{MgSO}_{4}, 99 \%\right)$ were purchased from Sigma-Aldrich (St. Louis, MO, USA) and were used without purification. The solvents $N$-vinylpyrrolidone (NVP, 99\%) and $\varepsilon$-caprolactone (CL, 99\%) were distilled and stored in a molecular sieve prior to use.

\subsection{Synthesis of 2-Hydroxyethyl 2-Bromopropanoate (HEB)}

As shown in Scheme S1a: 2-Bromopropanoyl bromide (10.2 g, $47.4 \mathrm{mmol})$ was dissolved in $50 \mathrm{~mL}$ of anhydrous THF and added dropwise to a solution of ethylene glycol (150 g, $2.42 \mathrm{~mol})$, pyridine $(3.75 \mathrm{~g}, 47.4 \mathrm{mmol})$, and $500 \mathrm{~mL}$ anhydrous THF at $0{ }^{\circ} \mathrm{C}$ within $1 \mathrm{~h}$. After the reaction finished, the mixture was diluted by hydrochloric acid to obtain a solution with a pH equal to 2 . The aqueous layer was then extracted three times with dichloromethane (DCM). The organic phase was combined and further washed with DI water. The organic layer was dried over anhydrous $\mathrm{MgSO}_{4}$ and evaporated under vacuum. A light pale yellow oil product (i.e., HEB) was obtained (yield $=5.2 \mathrm{~g}(55.8 \%) ;{ }^{1} \mathrm{H} \mathrm{NMR}$ $\left(400 \mathrm{MHz}, \mathrm{CDCl}_{3}, \delta=\mathrm{ppm}\right): 8.02-7.09(\mathrm{~d}, J=9 \mathrm{~Hz}, 2 \mathrm{H}), 7.40-7.36(\mathrm{~d}, J=9 \mathrm{~Hz}, 2 \mathrm{H}), 4.78(\mathrm{~s}, 2 \mathrm{H})$, $3.89(\mathrm{~s}, 3 \mathrm{H}), 0.94(\mathrm{~s}, 9 \mathrm{H})$, and $0.10(\mathrm{~s}, 6 \mathrm{H}))$.

\subsection{Synthesis of S-(1-Methyl-4-Hydroxyethyl Acetate) O-Ethyl Xanthate (MHEX)}

As consecutively shown in Scheme S1a: HEB (4.96 g, $25.3 \mathrm{mmol})$ was dissolved in $50 \mathrm{~mL}$ acetone and added dropwise to a solution of potassium ethyl xanthate $(4.51 \mathrm{~g}, 28.3 \mathrm{mmol})$ with $50 \mathrm{~mL}$ acetone at room temperature in $30 \mathrm{~min}$. After the reaction finished, the heterogeneous mixture was filtrated to remove the solid salt, and washed by acetone. The filtrate was then condensed by vacuum and diluted by DCM. The organic phase was washed with DI water, dried over $\mathrm{MgSO}_{4}$, and evaporated under vacuum. A pale yellow oil product (i.e., MHEX) was obtained (yield $=5.23 \mathrm{~g}(87.1 \%) ;{ }^{1} \mathrm{H} \mathrm{NMR}$ $\left(400 \mathrm{MHz}, \mathrm{CDCl}_{3}, \delta=\mathrm{ppm}\right.$ (see Figure S1a in the Supporting Information)): $1.42(\mathrm{t}, 3 \mathrm{H}), 1.60(\mathrm{~d}, 3 \mathrm{H})$, $1.85-2.00(\mathrm{~m}, 1 \mathrm{H}), 3.80-3.90(\mathrm{~m}, 2 \mathrm{H}), 4.28(\mathrm{qt}, 2 \mathrm{H}), 4.42(\mathrm{q}, 1 \mathrm{H})$, and $4.64(\mathrm{q}, 2 \mathrm{H}))$. 


\subsection{Synthesis of 3-Ethyl-1-Vinyl-2-Pyrrolidone $\left(C_{2} N V P\right)$}

The synthetic procedures were modified according to the previous study $[17,18]$. As shown in Scheme S1b: NVP (10 g, $90 \mathrm{mmol})$ was dissolved in $50 \mathrm{~mL}$ of dry THF, and added dropwise to $45 \mathrm{~mL}$ of a $2.0 \mathrm{M} \mathrm{LDA} / \mathrm{THF}$ solution $(90 \mathrm{mmol})$ at $0{ }^{\circ} \mathrm{C}$. After the addition, 1-bromoethane (10.3 g, $95 \mathrm{mmol})$ with $50 \mathrm{~mL}$ of dry THF was then added dropwise. After the reaction finished, the mixture was quenched by DI water $(100 \mathrm{~mL})$. DCM was added to extract the aqueous for three times. The organic phase was collected, dried over $\mathrm{MgSO}_{4}$, and evaporated under vacuum. The crude product was purified by flash chromatography (hexane/ethyl acetate $=4: 1(v / v)$ ), and yielded $4.48 \mathrm{~g}(35.8 \%)$ of $\mathrm{C}_{2} \mathrm{NVP}$ as a pale yellow oil $\left({ }^{1} \mathrm{H} \mathrm{NMR}\left(400 \mathrm{MHz}, \mathrm{CDCl}_{3}, \delta=\right.\right.$ ppm (see Figure $\mathrm{S} 1 \mathrm{~b}$ in the Supporting Information)): $0.98(\mathrm{t}, J=7.5 \mathrm{~Hz}, 3 \mathrm{H}), 1.45(\mathrm{~m}, 1 \mathrm{H}), 1.69-1.96(\mathrm{~m}, 2 \mathrm{H}), 2.22-2.54$ $(\mathrm{m}, 2 \mathrm{H}), 3.33-3.56(\mathrm{~m}, 2 \mathrm{H}), 4.38(\mathrm{~d}, \mathrm{~J}=16.0 \mathrm{~Hz}, 1 \mathrm{H}), 4.43(\mathrm{~d}, J=9.2 \mathrm{~Hz}, 1 \mathrm{H}), 7.10(\mathrm{dd}, J=15.98 \mathrm{~Hz}, 1 \mathrm{H})$; ${ }^{13} \mathrm{C} \mathrm{NMR}\left(150 \mathrm{MHz}, \mathrm{CDCl}_{3}, \delta=\mathrm{ppm}\right): 11.08,23.48,23.81,42.57,43.43,93.72,129.19$, and 174.74).

\subsection{Synthesis of Poly[(3-Ethyl-1-Vinyl-2-Pyrrolidone)-Co-(N-Vinyl-2-Pyrrolidone)] by RAFT Copolymerization (i.e., Copolymers C1-C6)}

An example of copolymer $\mathrm{C} 1$ (shown in Scheme 1): the ratio of reagents was $\left(\mathrm{C}_{2} \mathrm{NVP}+\mathrm{NVP}\right) /$ MHEX $/$ AIBN $=(20+10) / 1 / 0.1$ in EtOH $\left([M H E X]_{0}=75.5 \mathrm{mM}\right) . \mathrm{C}_{2} \mathrm{NVP}, \mathrm{NVP}, \mathrm{MHEX}, \mathrm{AIBN}$, and EtOH were added to a $25 \mathrm{~mL}$ Schlenk flask. The mixture was deoxygenated by three freeze-pump-thaw cycles. The flask was back-filled with nitrogen, an initial sample was taken via a syringe, and the flask was then kept at $70^{\circ} \mathrm{C}$ to carry out the RAFT copolymerization. After $24 \mathrm{~h}$, the reaction was stopped by placing the flask in an ice bath and exposing the contents to the air. The EtOH was removed under vacuum, and the residue was dissolved in DCM. The mixture was precipitated in n-hexane, and a white solid was obtained with a moderate yield ( $47.5 \%)$. The other copolymers (i.e., C2-C6) have the same procedures and were all characterized by FT-IR (see Figure S2 in the Supporting Information). The detailed information was summarized in Scheme 1 and Table 1.

\subsection{Chain Extension of $P\left(C_{2} N V P-C o-N V P\right)-O H$ with $C L$ by ROP (i.e., $\left.B C 1\right)$}

A Schlenk flask contained a heterogeneous mixture of macroinitiator C1 $\left(M_{n}=8350, M_{\mathrm{w}} / M_{\mathrm{n}}=1.34\right.$; $0.01 \mathrm{mmol})$, organocatalyst DPP $(0.01 \mathrm{mmol})$, and distilled monomer $\varepsilon$-caprolactone $(1 \mathrm{mmol})$. The mixture was placed in a thermostatted oil bath at $60{ }^{\circ} \mathrm{C}$ under a nitrogen atmosphere, and became homogeneous in $5 \mathrm{~min}$. After a desired period, the polymerization was quenched by exposure to the air and diluted by DCM. The mixture was precipitated in n-hexane. A yellowish white solid was obtained (i.e., $\mathrm{BC} 1: M_{\mathrm{n}}=10450, M_{\mathrm{w}} / M_{\mathrm{n}}=1.59$ ), and dried under reduced pressure (yield $50 \%$ ).

\subsection{Characterization}

${ }^{1} \mathrm{H}$ NMR measurements were performed using a Varian Inova 400 NMR (Varian, Billerica, MA, USA) in $\mathrm{CDCl}_{3}$, and the chemical shift was calibrated by setting the internal standard of $\mathrm{CDCl}_{3}$ as 7.26 ppm. FT-IR spectra were measured by a Nicolet Avatar 320 FT-IR Spectrometer (Nicolet, Madsion, WI, USA); 32 scans at a resolution of $1 \mathrm{~cm}^{-1}$ were conducted using a $\mathrm{KBr}$ disk. The dissolved samples were cast onto a $\mathrm{KBr}$ disk and dried under vacuum. The sample chamber was purged with nitrogen to maintain the film's dryness. The conversion of the monomers was monitored using a Hewlett Packard 5890 series II gas chromatograph (Hewlett Packard, Palo Alto, CA, USA) (GC) equipped with an FID detector, and employing a CNW CD-5 column $(30 \mathrm{~m})$ using anisole as an internal standard. Gel permeation chromatography (GPC) was conducted at $40{ }^{\circ} \mathrm{C}$ in dimethyl acetamide (DMAc) (flow rate: $1 \mathrm{~mL} / \mathrm{min}$ ), equipped with a Waters 515 pump, a Waters 410 differential refractometer, a Waters 486 absorbance detector, and two PSS SDV columns (Linear S and $100 \AA$ pore size) to obtain $M_{\mathrm{n}}, M_{\mathrm{w}}$ and $M_{\mathrm{w}} / M_{\mathrm{n}}$. Monodisperse polystyrene (PSt) standards were used for the calibrations. The cloud point temperatures (CPs) of the copolymers were determined by transmittance measurements in a quartz cell charged with a polymer concentration of $1 \mathrm{mg} / \mathrm{mL}$ in a 
PerkinElmer Lambda 25 UV-vis spectrometer (PerkinElmer, Waltham, MA, USA). The transmittance was monitored at 450-700 nm, and the data were collected after the solution was equilibrated for $2 \mathrm{~min}$ at each temperature. The $\mathrm{CP}$ was defined as the temperature when the transmittance decreased to $50 \%$. Various concentrations of block copolymer aqueous solutions were mixed with the same volume of pyrene aqueous solution with a concentration of $8 \times 10^{-7} \mathrm{M}$. The mixtures were filtered through a $0.22 \mu \mathrm{m}$ Millipore filter into a dust-free vial beforehand, to detect the critical micelle concentration (CMC). The CMC measurements were performed using a HITACHI F-2500 fluorescence spectroscopy (HITACHI, Tokyo, Japan) scanned during 300-500 nm, which conducted $250 \mathrm{~nm}$ as the excitation wavelength. Particle sizes were measured by laser light scattering (LLS) of a commercial spectrometer (Brookhaven Inc., Holtsville, NY, USA) equipped with a BI-200SM goniometer and a BI-9000AT digital autocorrelator. A $15 \mathrm{~mW}$ vertically polarized solid-state laser $(630 \mathrm{~nm})$ was used as the light source. At each heating/cooling step, the solutions were equilibrated for $5 \mathrm{~min}$ in a thermostatted bath. For the dynamic light scattering measurements, the intensity-intensity time autocorrelation function was measured in the self-beating mode. The Laplace inversion program-CONTIN—was applied, to obtain the average line width $\Gamma$ with a varying scattering angle $q$. The apparent hydrodynamic radius $\left(R_{\mathrm{h}}\right)$ was obtained by extrapolating $\Gamma / \mathrm{q} 2$ to an angle of zero, and was estimated from the Stokes-Einstein equation.

\section{Results and Discussion}

To synthesize copolymers with a different molecular weight (MW), we first used a molar feed of $\mathrm{C}_{2} \mathrm{NVP} / \mathrm{NVP}=66: 34$ with the different monomers/RAFT agent ratios (i.e., $\mathrm{M} / \mathrm{MHEX}$ ) of 30, 60, and 200 to synthesize the various MWs of the PNVP-based copolymers. In this copolymerization ratio, we expect the cloud points (CPs) of the copolymers to be close to our body temperature. The composition of the copolymers was estimated by ${ }^{1} \mathrm{H}$ NMR analysis (Figure 1A) and the results are summarized in Table 1. From the ratio of the assigned 1-3 peaks (i.e., $A_{3} /\left(A_{1}+A_{2}\right)$ ) [51], we acquired all of the copolymers with similar content (i.e., $\mathrm{C}_{2} \mathrm{NVP}(\mathrm{mol} \%)$ in $\mathrm{C} 1(64.0 \%), \mathrm{C} 2(64.6 \%)$ and C3 (63.9\%)). Figure 1B showed the GPC traces of the related copolymers. Controlled MWs with mono-disperse and narrow molecular weight distributions (MWDs (i.e., $M_{\mathrm{w}} / M_{\mathrm{n}}$ )] were obtained (C1: $M_{n}=8350, C 2: M_{n}=11,590$ and C3: $M_{n}=15,300 ;$ all $\left.M_{\mathrm{w}} / M_{\mathrm{n}}<1.5\right)$. We demonstrated one of the RAFT copolymerizations $\left(C_{2} \mathrm{NVP} / \mathrm{NVP}=66: 34\right.$ and $\left.\mathrm{M} / \mathrm{MHEX}=200\right)$ by $\mathrm{GC}$ to observe the kinetic behavior. As shown in Figure 2, linear pseudo-first order relationships and moderate polymerization rates were observed from each monomer. The apparent reaction rate of $\mathrm{C}_{2} \mathrm{NVP}$ and NVP were $k_{\mathrm{app}\left(\mathrm{C}_{2} \mathrm{NVP}\right)}=3.45 \times 10^{-5} \mathrm{~s}^{-1}$ and $k_{\mathrm{app}(\mathrm{NVP})}=3.28 \times 10^{-5} \mathrm{~s}^{-1}$, respectively. These results implied an ease of MW control and similar monomer reactivity through RAFT copolymerizations using the MHEX chain transfer agent.
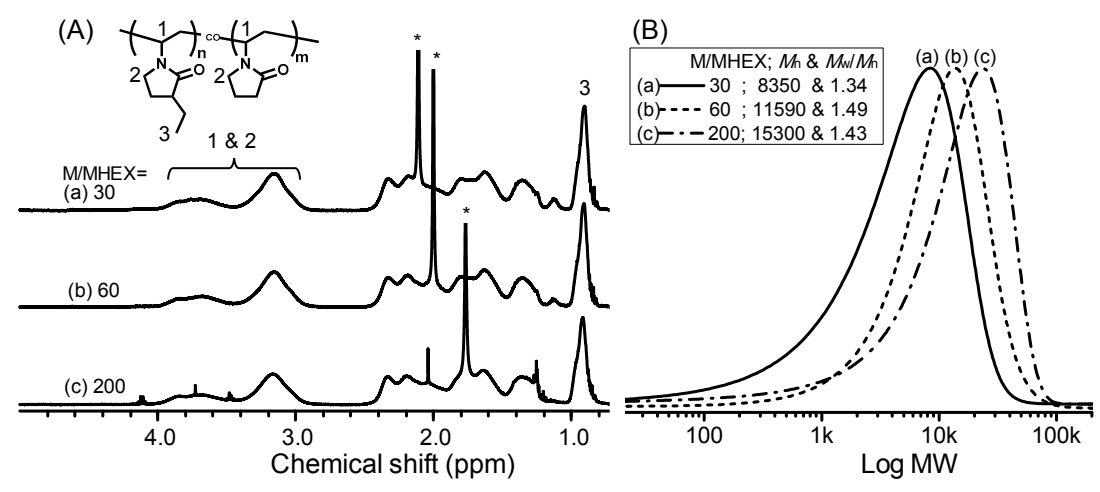

Figure 1. C1-C3 copolymers of (A) ${ }^{1} \mathrm{H}$ NMR spectra $\left(400 \mathrm{MHz}, \mathrm{CDCl}_{3}\right)$; (B) GPC traces through RAFT copolymerization of $N$-vinylpyrrolidone (NVP)and 3-ethyl-1-vinyl-2-pyrrolidone $\left(\mathrm{C}_{2} \mathrm{NVP}\right)$ with different M/MHEX ratios (*: impurities). 


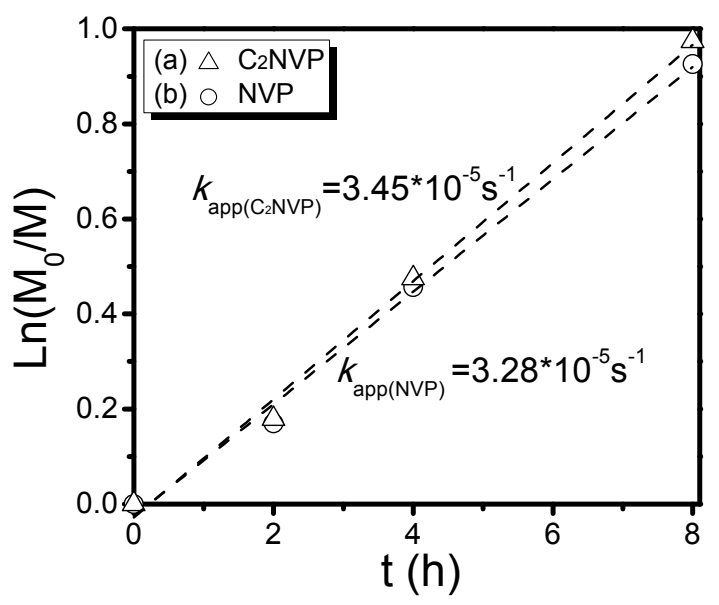

Figure 2. Kinetic of RAFT copolymerization of $\mathrm{C}_{2}$ NVP and NVP (Monomers $/ \mathrm{MHEX}=200 / 1$ in EtOH at $70{ }^{\circ} \mathrm{C} ;\left[\mathrm{C}_{2} \mathrm{NVP}\right]_{0}=1.50 \mathrm{M}$ and $\left.[\mathrm{NVP}]_{0}=0.75 \mathrm{M}\right)$.

To synthesize various composition of PNVP-based copolymers, we then used a molar ratio of $\mathrm{M} / \mathrm{MHEX}=200$ with different concentrations of $\mathrm{C}_{2} \mathrm{NVP}$ in feed (i.e., 60, 66, 80, and $90 \mathrm{~mol} \%$ ). As shown in Figure $3 \mathrm{~A}$, similar MWs of copolymers $\left(M_{\mathrm{n}} \approx 15,000\right)$ with narrow MWDs were observed from GPC traces. Figure 3B displays the ${ }^{1} \mathrm{H}$ NMR spectra of the corresponding copolymers. As mentioned above, we acquired the compositions of the copolymers based on the assigned 1-3 peaks [i.e., $\mathrm{A}_{3} /\left(\mathrm{A}_{1}+\mathrm{A}_{2}\right)$ ] that afforded $\mathrm{C}_{2} \mathrm{NVP}_{\text {copolym }}(\mathrm{mol} \%)$ of $\mathrm{C} 4(60.8 \%), \mathrm{C} 5(82.3 \%)$, and $\mathrm{C} 6(89.9 \%)$. To study the sequence distribution of each monomer, the reactivity ratios of $\mathrm{C}_{2} \mathrm{NVP}\left(r_{\mathrm{C} 2 \mathrm{NVP}}\right)$ and NVP $\left(r_{\mathrm{NVP}}\right)$ were estimated by employing the Kelen-Tüdos method. We can estimate the reactivity ratio from the well-known copolymerization equation [i.e., $\eta=\left(r_{1}+\frac{r_{2}}{\alpha}\right) \xi-\frac{r_{2}}{\alpha}$ ], which contains two parameters, $\eta$ and $\xi$, from which the reactivity ratio is derived, as described in previous studies [28,52]. Figure 4 showed the Kelen-Tüdos plot of $\mathrm{C}_{2} \mathrm{NVP}$ and NVP copolymerizations. Applying a linear regression of $\eta$ and $\xi$ parameters, the reactivity ratios of NVP $\left(r_{\mathrm{NVP}}=0.995\right)$ and $\mathrm{C}_{2} \mathrm{NVP}\left(r_{\mathrm{C}_{2} \mathrm{NVP}}=1.021\right)$ were obtained. NVP showed a reactivity similar to $\mathrm{C}_{2} \mathrm{NVP}$ during RAFT copolymerization, implying that the system performed a predominantly ideal random distribution of the monomer units. The glassy transition temperatures $\left(T_{\mathrm{g}}\right)$ of these copolymers were determined by DSC. As shown in Figure S3 (see Supporting Information), the $T_{\mathrm{gS}}$ of $\mathrm{C} 1-\mathrm{C} 3$ copolymers increased from 95 to $121{ }^{\circ} \mathrm{C}$ with an increase in MW from ca. 8000 to 15,000 owing to the enhancement of chain entanglements. With different composition, the $T_{\mathrm{g}}$ of $\mathrm{C} 3-\mathrm{C} 6$ copolymers decreased from 130 to $114{ }^{\circ} \mathrm{C}$ with the increase in the $\mathrm{C}_{2} \mathrm{NVP}$ unit, which is ascribed to the lower $T_{\mathrm{g}}$ part of $\mathrm{PC}_{2} \mathrm{NVP}$ in copolymers (i.e., $\mathrm{T}_{\mathrm{g}, \mathrm{PC}_{2} \mathrm{NVP}}=88^{\circ} \mathrm{C}$, shown in Figure S3). A thermogravimetric analyzer (TGA) was utilized to trace thermal stabilities of the C1-C6 random copolymers. As shown in Figure S4 (see Supporting Information), the copolymers had similar decomposition profiles, possessing over $350{ }^{\circ} \mathrm{C}$ of the $5 \%$ decomposition temperature, implying good thermal stabilities of the $\mathrm{P}\left(\mathrm{C}_{2} \mathrm{NVP}-\mathrm{co}-\mathrm{NVP}\right)$ copolymers.

Table 1. Characterization of $\mathrm{P}\left(\mathrm{C}_{2} \mathrm{NVP}-\mathrm{co}-\mathrm{NVP}\right)$ copolymers (C1-C6).

\begin{tabular}{ccccccc}
\hline No. & {$[\mathbf{M}] /[\mathbf{I I}]^{\mathbf{a}}$} & $\mathbf{C}_{\mathbf{2}} \mathbf{N V P}_{\text {feed }}(\mathbf{m o l} \mathbf{\%})$ & $\mathbf{C}_{\mathbf{2}} \mathbf{N V P}_{\text {copolym }}{ }^{\mathbf{b}}(\mathbf{m o l} \%)$ & $\boldsymbol{M}_{\mathbf{n}}{ }^{\mathbf{c}}$ & $\boldsymbol{M}_{\mathbf{w}} / \boldsymbol{M}_{\mathbf{n}}{ }^{\mathbf{c}}$ & $\mathbf{C P}\left({ }^{\circ} \mathbf{C}\right)$ \\
\hline C1 & 30 & 66.7 & 64.0 & 8350 & 1.34 & 50.5 \\
C2 & 60 & 66.7 & 64.6 & 11,580 & 1.42 & 47.9 \\
C3 & 200 & 66.7 & 63.9 & 15,300 & 1.49 & 45.0 \\
C4 & 200 & 60.0 & 60.8 & 15,790 & 1.49 & 47.9 \\
C5 & 200 & 80.0 & 82.3 & 15,430 & 1.48 & 34.6 \\
C6 & 200 & 90.0 & 89.9 & 13,930 & 1.43 & 29.4 \\
\hline
\end{tabular}

${ }^{\mathrm{a}}[\mathrm{M}] /[\mathrm{I}]=\left(\left[\mathrm{C}_{2} \mathrm{NVP}\right]+[\mathrm{NVP}]\right) /[\mathrm{MHEX}] ;^{\mathrm{b}}$ Estimated from peak areas in ${ }^{1} \mathrm{H}$ NMR spectra (i.e., Figures 1 and 3$)$ : $\mathrm{A}_{3} /\left(\mathrm{A}_{1}+\mathrm{A}_{2}\right) ;{ }^{c} M_{\mathrm{n}}$ and $M_{\mathrm{w}} / M_{\mathrm{n}}$ were estimated by GPC (eluent: DMAc) using polystyrene as the standard. 

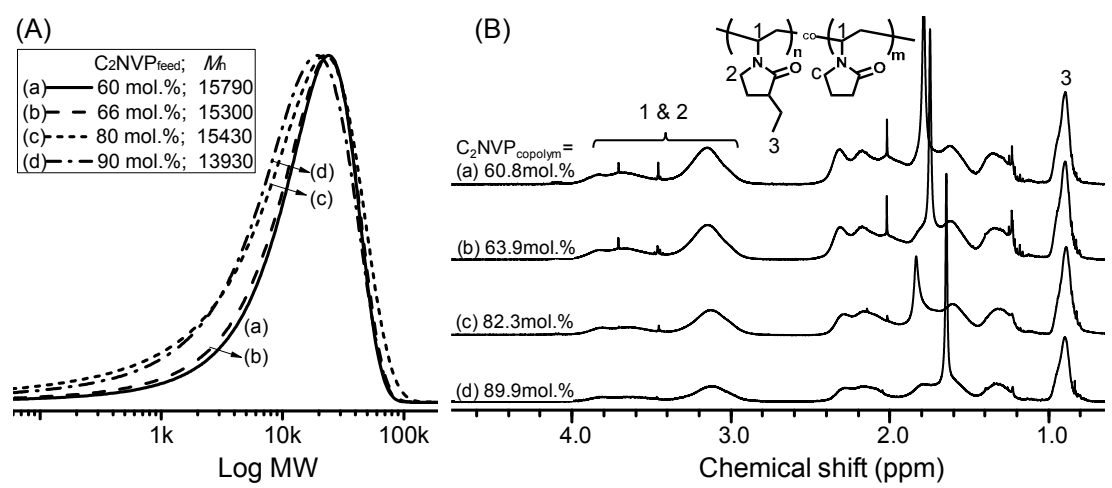

Figure 3. Kinetic C3-C6 copolymers of (A) GPC traces and (B) ${ }^{1} \mathrm{H}$ NMR spectra $\left(400 \mathrm{MHz}, \mathrm{CDCl}_{3}\right)$ through RAFT copolymerization different monomer feed ratios $\left(\mathrm{C}_{2} \mathrm{NVP}_{\text {feed }}=60,66,80\right.$, and $90 \mathrm{~mol} \%$; $\mathrm{M} / \mathrm{MHEX} / \mathrm{AIBN}=200 / 1 / 0.1$ in $\mathrm{EtOH}$ at $70^{\circ} \mathrm{C}$ ).

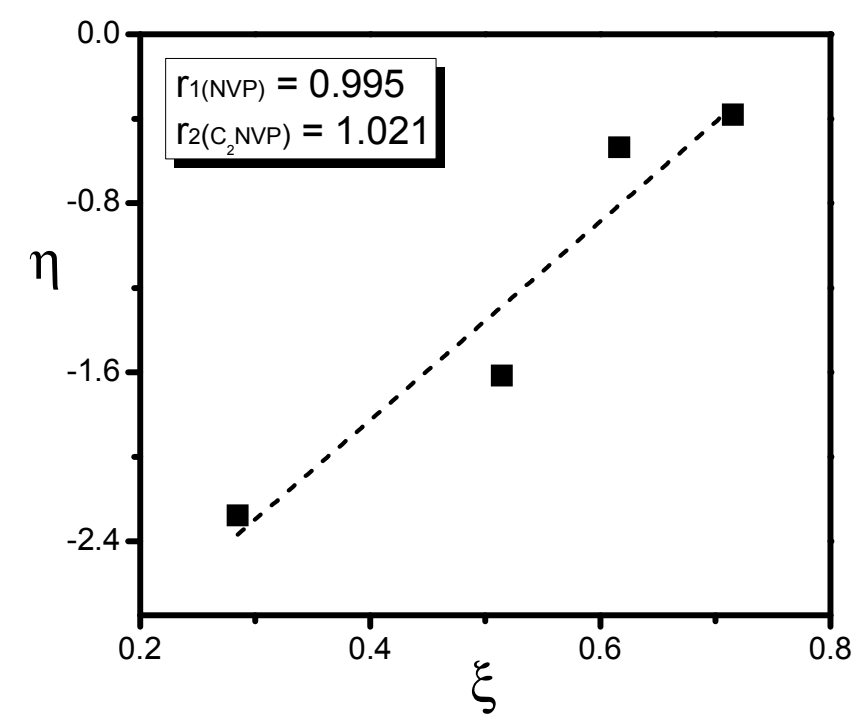

Figure 4. Kelen-Tüdos plot of RAFT copolymerization of $\mathrm{C}_{2} \mathrm{NVP}$ and NVP.

With control of copolymer MW and composition, the temperature-responsive properties of these random copolymers were then examined by UV/vis spectroscopy at different temperatures. LCST behaviors of the copolymer solutions $(1 \mathrm{mg} / \mathrm{mL})$ were recorded in a wavelength range of 450-700 $\mathrm{nm}$. Figure S5 displays the transmittance traces with different wavelength of a representative copolymer (i.e., C3) and shows that transmittance decreased with the increase in temperature. Among the curves in Figure S5, the line of the wavelength of $500 \mathrm{~nm}$ (bold-line) performed a clear LCST trend (i.e., cloud point $(\mathrm{CP}) \approx 45^{\circ} \mathrm{C}$ ) and was chosen to monitor the LCST trends of the copolymers C1-C6 efficiently. We then compared the MW effect on the CP of the PNVP-based random copolymers. Figure 5 showed the LCST behaviors of the copolymers with various MWs [i.e., C1 $\left(M_{n}=8350\right), C 2\left(M_{n}=11,580\right)$, and C3 $\left.\left(M_{n}=15,790\right)\right]$. The CPs decreased from 50.5 to $45.0{ }^{\circ} \mathrm{C}$ with the increase in the MW of copolymers with similar composition. The CPs linearly decreased with the increase in $M_{n}$ (the inset in Figure 5). It has been reported that the neat $\mathrm{PC}_{2} \mathrm{NVP}$ with different MWs from 2500 to 16,000 has nearly no effect on the CPs [17]. With the copolymerization of $\mathrm{C}_{2} \mathrm{NVP}$ and NVP, we revealed a new analogue of tunable thermosensitivity of $\mathrm{P}\left(\mathrm{C}_{2} \mathrm{NVP}-\mathrm{co}-\mathrm{NVP}\right)$ copolymers through the control of the $\mathrm{MW}$ from ca. 8000 to 16,000. As shown in Figure 6, on the other hand, we examined the composition effect on the CPs of the copolymers with similar MWs [i.e., C3-C6 $\left.\left(M_{\mathrm{n}} \approx 15,000\right)\right]$. The CPs of the copolymers 
decreased from ca. 48 to $29{ }^{\circ} \mathrm{C}$ with the increase in $\mathrm{C}_{2} \mathrm{NVP}$ content (i.e., from 60.8 to $89.9 \mathrm{~mol} \%$ ). The variation of CPs can be fitted by the theoretical equation [53]:

$$
C P=\frac{\mu_{1} C P_{1}+K \mu_{2} C P_{2}}{\mu_{1}+K \mu_{2}}
$$

where $\mu_{\mathrm{i}}$ is the molar fraction of $i$ monomer, $\mu_{1}+\mu_{2}=1$, and $K$ is a weighing parameter that indicates the interaction character between polymer chain and solvent molecules. Herein, the $\mathrm{CP}_{2}$ (i.e., $\mathrm{CP}$ of $\mathrm{PNVP}$ ) cannot be determined under ordinary conditions due to the boiling point of water. The $\mathrm{CP}_{2}$ of $170{ }^{\circ} \mathrm{C}$ was then obtained from the previous literature [54]. Further combining CPs of our values and previous literature [19], Figure 7 shows the plot of CPs vs. NVP molar fractions with theoretical fitting lines. In the ideal case [i.e., $K=1$ (Figure 7a line)], the trend of CPs and NVP concentrations shows a linear relationship. By fitting the experimental data (i.e., squares and circles in Figure 7 ), $K=0.23$ was obtained (i.e., the red-dash curve in Figure $7 \mathrm{~b}$ ). The low value of weighing parameter derived from the $\mathrm{P}\left(\mathrm{C}_{2} \mathrm{NVP}-\mathrm{co}-\mathrm{NVP}\right)$ copolymers illustrated that the introduction of the hydrophobic unit of the $\mathrm{C}_{2} \mathrm{NVP}$ monomer hindered the hydrophilic interaction between the polymer chain and the water and resulted in a decrease in the LCST of the copolymers.

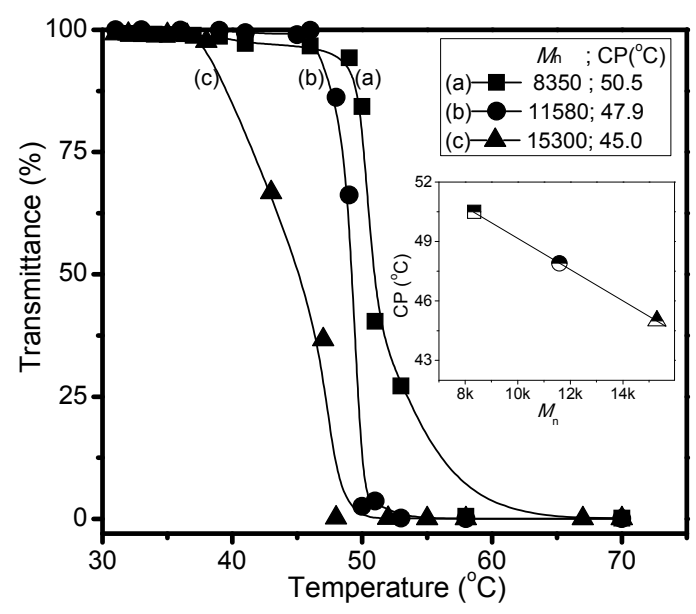

Figure 5. Plot of lower critical solution temperature (LCST) trends of copolymers with different molecular weights (MWs) and linear correlation curve $\left(\mathrm{C}_{2} \mathrm{NVP} \mathrm{mol} \%\right.$ in copolymer $\approx 64 \%$; conc. $=1 \mathrm{mg} / \mathrm{mL}$ ).

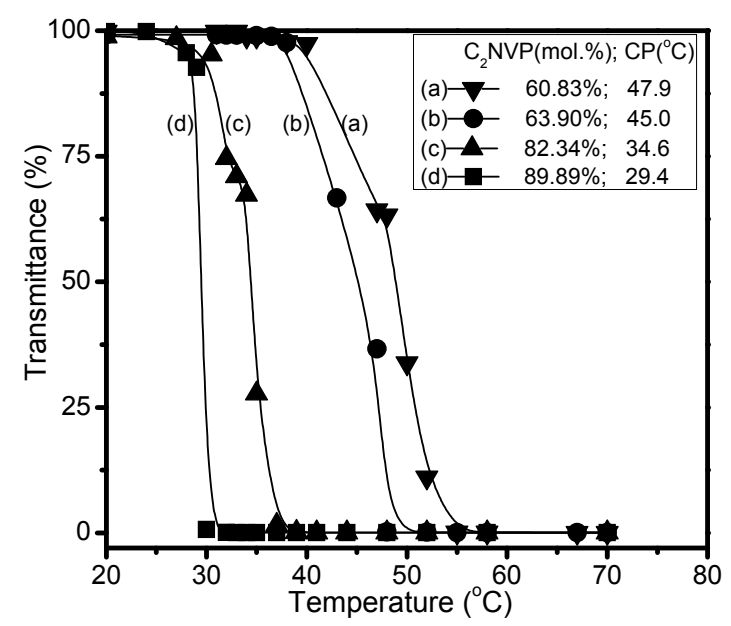

Figure 6. Plot of LCST trends of copolymers with different compositions $\left(M_{\mathrm{n}} \approx 15300\right.$; conc. $=1 \mathrm{mg} / \mathrm{mL}$ ). 


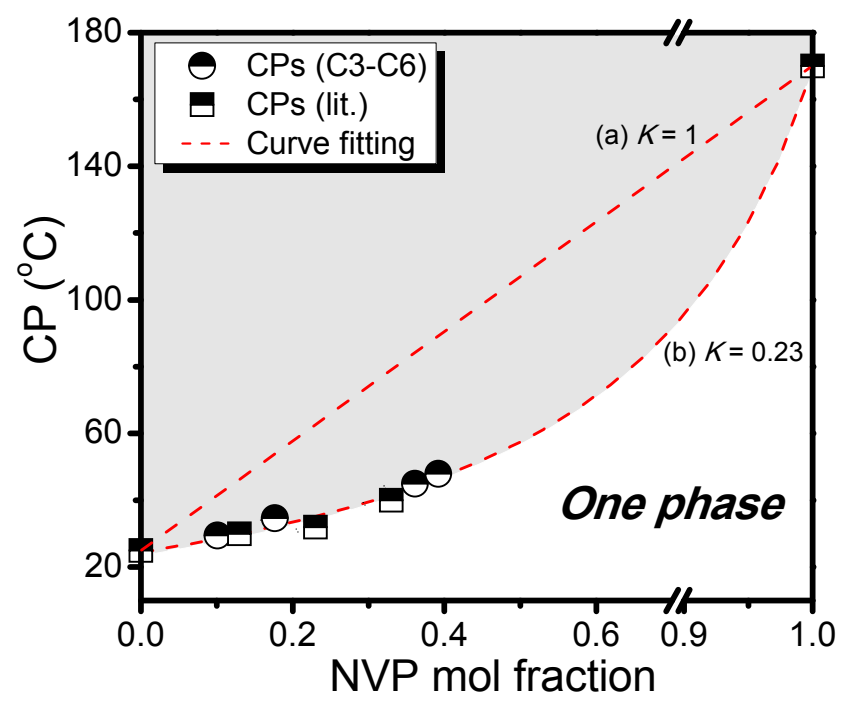

Figure 7. Experimental and theoretical plots of cloud points (CPs) vs. NVP molar fractions in the $\mathrm{P}\left(\mathrm{C}_{2} \mathrm{NVP}-\mathrm{co}-\mathrm{NVP}\right)$ copolymers.

We then proceeded with the chain extension of a macroinitiator possessing hydroxyl chain end through ROP of CL monomer using an organocatalyst and analyzed the results by GPC and ${ }^{1} \mathrm{H}$ NMR spectroscopy. In the GPC traces (i.e., Figure 8A), the MW from the macroinitiator [i.e., (a) C1: $M_{n, G P C}=8350, M_{w} / M_{n}=1.34$ ] shifted to a higher MW [i.e., (b) $M_{n, G P C}=10450$ ] and remained mono-disperse with a MWD of 1.59 after chain extension. In the ${ }^{1} \mathrm{H}$ NMR spectra (i.e., Figure 8B), the major peaks of $\mathrm{C} 1$ and $\mathrm{BC} 1$ could be assigned from their $\mathrm{P}\left(\mathrm{C}_{2} \mathrm{NVP}-\mathrm{co}-\mathrm{NVP}\right)$ and $\mathrm{PCL}$ segments (i.e., Peaks 1-3 for $\mathrm{P}\left(\mathrm{C}_{2} \mathrm{NVP}-\mathrm{co}-\mathrm{NVP}\right)$ and Peak 4 for $\mathrm{PCL}$, respectively). We then acquired the $M_{n, \mathrm{NMR}}$ of BC1 with a value of ca. 14730. The difference in $M_{n}$ s measured by GPC and NMR were reasonably ascribed to the different hydrodynamic volumes between the block copolymers and the PSt calibration standards. Characterization of the BC1 data is summarized in Table S1 (see Supporting Information).
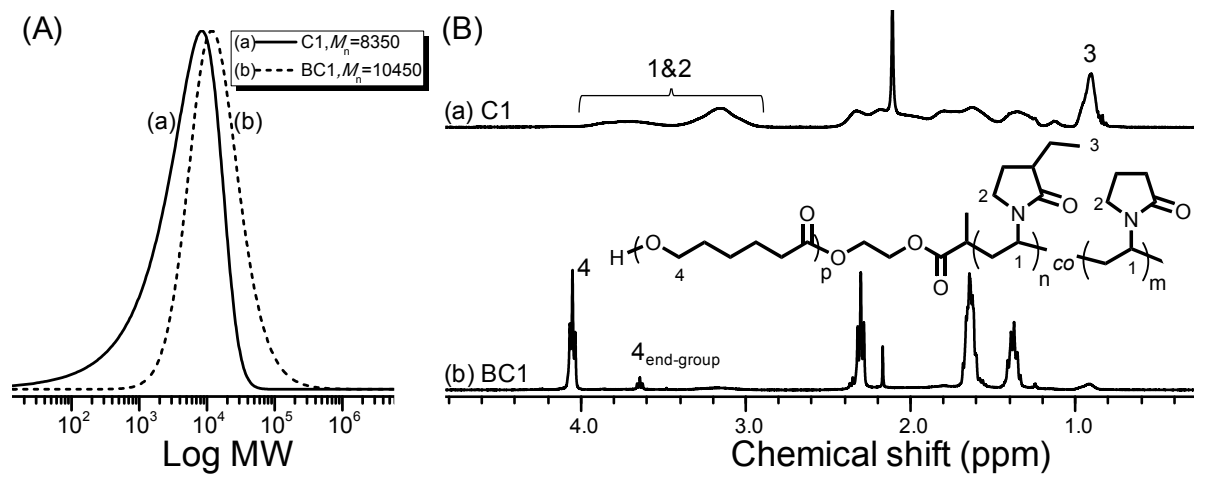

Figure 8. (A) GPC traces and (B) ${ }^{1} \mathrm{H}$ NMR spectra (400 MHz, $\mathrm{CDCl}_{3}$ ) of (a) $\mathrm{C} 1$ and (b) $\mathrm{BC} 1$ copolymers.

We thus expect that the $\mathrm{P}\left(\mathrm{C}_{2} \mathrm{NVP}-\mathrm{co}-\mathrm{NVP}\right)-b$-PCL block copolymer composing hydrophobic and hydrophilic segments can be applied to the fabrication of thermo-responsive micelles. To determine the critical micelle concentration $(\mathrm{CMC})$ of $\mathrm{BC} 1$, fluorescence measurements of micelle solutions with different concentrations using pyrene as a probe were conducted. Based on the intensity ratios of 340 and $380 \mathrm{~nm}$ from pyrene probe and BC1 concentrations, the plot of $I_{380} / I_{340} \mathrm{vs}$. Log C can be obtained (as shown in Figure 9). We can acquire an obvious decline point of $I_{380} / I_{340}$ around $1.46 \times 10^{-4} \mathrm{~g} / \mathrm{L}$. The rapid decrease in the intensity ratio was ascribed to the isolation of pyrene probe efficiently encapsulated through the formed micelles (i.e., CMC of BC1). To measure the thermosensitivity of 
the micelle size, a solution with a $\mathrm{BC} 1$ concentration of $0.002 \mathrm{~g} / \mathrm{L}$ was monitored by dynamic light scattering (DLS) at 25 and $55{ }^{\circ} \mathrm{C}$, respectively. At $25^{\circ} \mathrm{C}$ (Figure 10a), a mono-disperse distribution with a particle size of ca. $240 \mathrm{~nm}$ was obtained. At $55^{\circ} \mathrm{C}$ (Figure 10b), a mono-disperse particle size but with a smaller particle size of ca. $140 \mathrm{~nm}$ was obtained. This is a typical thermoresponsive behavior of a micelle containing an LCST segment. Namely, the hydrogen bonding of the polymer chain and water molecules breaks when the solution temperature over the LCST is elevated, and leads to shrinkages of the thermoresponsive polymer chains on the micelle surface. We thus investigated a novel analogue of the LCST block copolymer comprising a thermoresponsive $\mathrm{P}\left(\mathrm{C}_{2} \mathrm{NVP}-\mathrm{co}-\mathrm{NVP}\right)$ segment (i.e., hydrophilic compartment) and a biodegradable PCL segment (i.e., hydrophobic compartment).

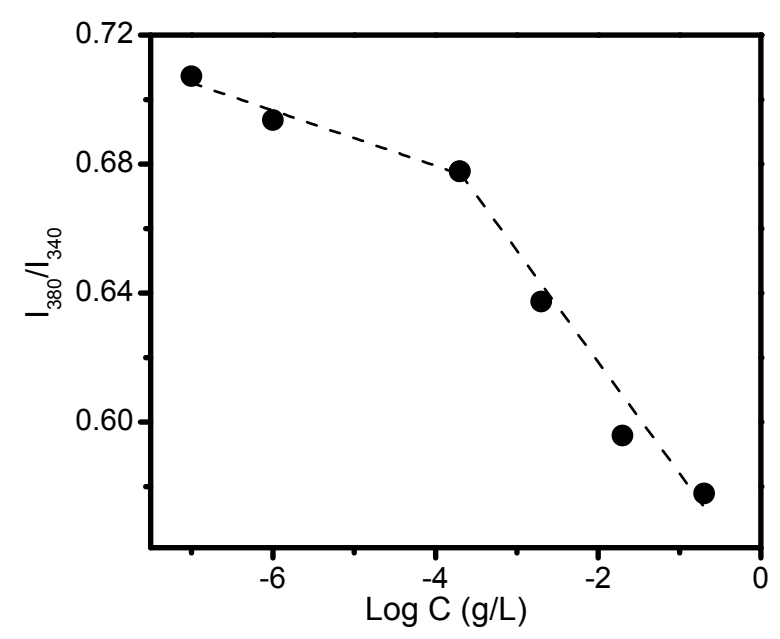

Figure 9. Critical micelle concentration (CMC) examination of $\mathrm{P}\left(\mathrm{C}_{2} \mathrm{NVP}-c o-\mathrm{NVP}\right)-b$-PCL block copolymer by using pyrene as a probe.

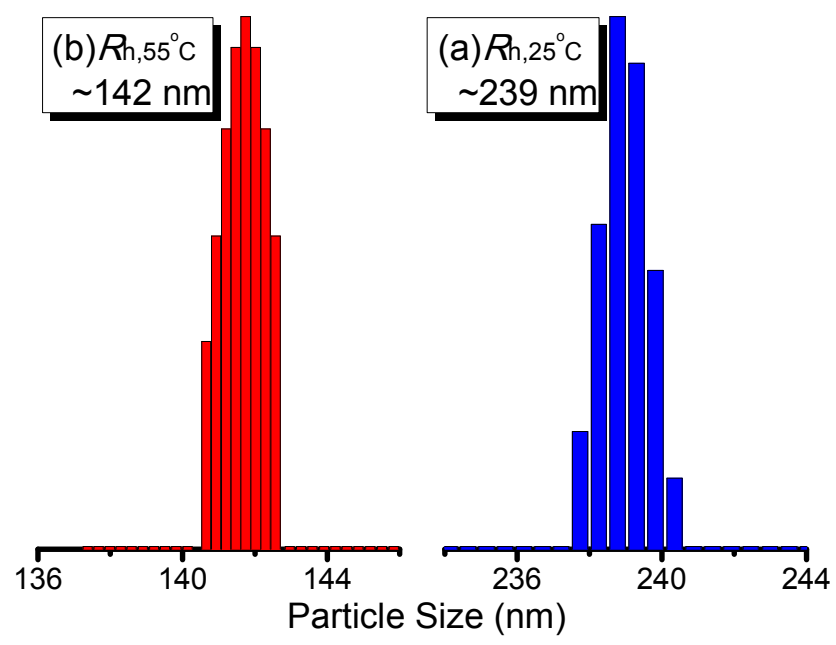

Figure 10. Hydrodynamic radii $\left(R_{\mathrm{h}}\right)$ of $\mathrm{P}\left(\mathrm{C}_{2} \mathrm{NVP}-c o-\mathrm{NVP}\right)-b$-PCL block copolymer measured by DLS at $(\mathbf{a}) 25^{\circ} \mathrm{C}$ and (b) $55^{\circ} \mathrm{C}$ (conc. of BC1 $=0.002 \mathrm{~g} / \mathrm{L}$ ).

\section{Conclusions}

Through the RAFT copolymerization, we first synthesized a series of well-defined $\mathrm{P}\left(\mathrm{C}_{2} \mathrm{NVP}-\mathrm{co}-\mathrm{NVP}\right)$ copolymers possessing different MWs $\left(M_{\mathrm{n}} \approx 8000-15,000\right)$ and narrow MWDs $\left(M_{\mathrm{w}} / M_{\mathrm{n}}<1.5\right)$ using a difunctional chain transfer agent (i.e., MHEX). From the kinetic study, similar apparent rate constants of NVP and $\mathrm{C}_{2} \mathrm{NVP}$ monomers were obtained $\left(k_{\text {app }} \approx 3 \times 10^{-5} \mathrm{~s}^{-1}\right)$. With the copolymerization of different monomer ratios in feeds, reactivity ratios of NVP $\left(r_{\mathrm{NVP}}=0.995\right)$ 
and $\mathrm{C}_{2} \mathrm{NVP}\left(r_{\mathrm{C}_{2} \mathrm{NVP}}=1.021\right)$ can be further estimated by the Kelen-Tüdos method, indicating predominantly ideal random copolymerization of the monomers. $T_{\mathrm{g}} \mathrm{s}$ increased with the increase in copolymer MWs and NVP contains. Regardless of MW and copolymer composition, the copolymers possessed a similar $5 \%$ decomposition temperature of ca. $350{ }^{\circ} \mathrm{C}$. Monitoring by UV/Vis spectroscopy, the CPs decreased linearly from 50.5 to $45.0^{\circ} \mathrm{C}$ with the increase in MWs from $M_{n}=8350$ to 15,790 . We revealed an analogue of tunable thermosensitivity of $\mathrm{P}\left(\mathrm{C}_{2} \mathrm{NVP}-\mathrm{co}-\mathrm{NVP}\right)$ copolymers through the control of the MW. Further examining the composition effects with a similar MW, the CPs of the copolymers decreased from ca. 48 to $29{ }^{\circ} \mathrm{C}$ with the increase in $\mathrm{C}_{2} \mathrm{NVP}$ content (i.e., from 60.8 to $89.9 \mathrm{~mol} \%$ ). Fitting the CPs by the theoretical equation, the low value of weighing parameter $(K=0.23)$ illustrated the introduction of more hydrophobic unit of $C_{2}$ NVP monomer suppressed the hydrophilic interaction between polymer chain and water. We then successfully proceeded the chain extension by ROP of $\mathrm{CL}$ to the synthesis of $\mathrm{P}\left(\mathrm{C}_{2} \mathrm{NVP}-c o-\mathrm{NVP}\right)-b$-PCL amphiphilic block copolymer $\left(M_{\mathrm{n}, \mathrm{NMR}}=14,730\right.$ and $\left.M_{\mathrm{w}} / M_{\mathrm{n}}=1.59\right)$. Probing by fluorescent chromophore, $\mathrm{CMC}$ of the block copolymer had a value of ca. $1.46 \times 10^{-4} \mathrm{~g} / \mathrm{L}$. The micelle sizes with mono-disperse distribution were ca. $240 \mathrm{~nm}$ at $25^{\circ} \mathrm{C}$ and ca. $140 \mathrm{~nm}$ at $55^{\circ} \mathrm{C}$, respectively. The thermosensitive nano-carrier composing $\mathrm{P}\left(\mathrm{C}_{2} \mathrm{NVP}-\mathrm{co}-\mathrm{NVP}\right)-b$ - $\mathrm{PCL}$ has a potential for use with biomaterials, drug and gene delivery systems, diagnostic imaging, and tissue engineering.

Supplementary Materials: The following are available online at www.mdpi.com/9/6/231/s1. Table S1: Characterization of $\mathrm{P}\left(\mathrm{C}_{2} \mathrm{NVP}-\mathrm{co}-\mathrm{NVP}\right)-b$-PCL copolymers (BC1); Scheme S1: Synthetic routes of (a) MHEX and (b) $\mathrm{C}_{2} \mathrm{NVP}$; Figure S1: ${ }^{1} \mathrm{H}$ NMR spectra $\left(400 \mathrm{MHz}, \mathrm{CDCl}_{3}\right)$ of (A) MHEX and (B) $\mathrm{C}_{2} \mathrm{NVP}$ compounds; Figure S2: FT-IR spectra of C1-C6 copolymers; Figure S3: DSC traces of C1-C6 copolymers (record of 2nd heating run with ramp $20^{\circ} \mathrm{C} /$ min under $\mathrm{N}_{2}$ ); Figure S4: TGA traces of C1-C6 copolymers (ramp $20^{\circ} \mathrm{C} /$ min under $\mathrm{N}_{2}$ ); Figure S5: LCST behaviors scanned with different wavelength (C3 copolymer: $1 \mathrm{mg} / \mathrm{mL}$ ).

Acknowledgments: We thank the Ministry of Science and Technology (MOST105-2221-E-005-084-MY2, MOST106-2923-E-194-001, and MOST105-2628-E-005-003-MY3) for financial support.

Author Contributions: Chih-Feng Huang and Yi-Shen Huang conceived and designed the experiments; Yi-Shen Huang performed the experiments; Chih-Feng Huang and Yi-Shen Huang analyzed the data; Jem-Kun Chen and Tao Chen designed and contributed the thermal-responsive tests; Chih-Feng Huang and Yi-Shen Huang wrote the paper.

Conflicts of Interest: The authors declare no conflict of interest.

\section{References}

1. Stuart, M.A.C.; Huck, W.T.S.; Genzer, J.; Müller, M.; Ober, C.; Stamm, M.; Sukhorukov, G.B.; Szleifer, I.; Tsukruk, V.V.; Urban, M.; et al. Emerging applications of stimuli-responsive polymer materials. Nat. Mater. 2010, 9, 101-113. [CrossRef] [PubMed]

2. Liu, F.; Urban, M.W. Recent advances and challenges in designing stimuli-responsive polymers. Prog. Polym. Sci. 2010, 35, 3-23. [CrossRef]

3. Liu, R.; Fraylich, M.; Saunders, B.R. Thermoresponsive copolymers: From fundamental studies to applications. Colloid Polym. Sci. 2009, 287, 627-643. [CrossRef]

4. Dimitrov, I.; Trzebicka, B.; Müller, A.H.E.; Dworak, A.; Tsvetanov, C.B. Thermosensitive water-soluble copolymers with doubly responsive reversibly interacting entities. Prog. Polym. Sci. 2007, 32, 1275-1343. [CrossRef]

5. Gil, E.; Hudson, S. Stimuli-reponsive polymers and their bioconjugates. Prog. Polym. Sci. 2004, 29, 1173-1222. [CrossRef]

6. Katsumoto, Y.; Etoh, Y.; Shimoda, N. Phase diagrams of stereocontrolled poly $(N, N$-diethylacrylamide $)$ in water. Macromolecules 2010, 43, 3120-3121. [CrossRef]

7. Maeda, Y.; Sakamoto, J.; Wang, S.-Y.; Mizuno, Y. Lower critical solution temperature behavior of poly( $N$-(2-ethoxyethyl)acrylamide) as compared with poly( $N$-isopropylacrylamide). J. Phys. Chem. B 2009, 113, 12456-12461. [CrossRef] [PubMed]

8. Schmitz, S.; Ritter, H. Access to poly\{N-[3-(dimethylamino)propyl](meth)acrylamide\} via microwave-assisted synthesis and control of LCST-behavior in water. Macromol. Rapid Commun. 2007, 28, 2080-2083. [CrossRef] 
9. Roth, P.J.; Jochum, F.D.; Forst, F.R.; Zentel, R.; Theato, P. Influence of end groups on the stimulus-responsive behavior of poly[oligo(ethylene glycol) methacrylate] in water. Macromolecules 2010, 43, 4638-4645. [CrossRef]

10. Maeda, Y.; Yamauchi, H.; Kubota, T. Confocal micro-raman and infrared spectroscopic study on the phase separation of aqueous poly(2-(2-methoxyethoxy)ethyl (meth)acrylate) solutions. Langmuir 2009, 25, 479-482. [CrossRef] [PubMed]

11. Zhao, J.; Hoogenboom, R.; Van Assche, G.; Van Mele, B. Demixing and remixing kinetics of poly(2-isopropyl-2-oxazoline) (PIPOZ) aqueous solutions studied by modulated temperature differential scanning calorimetry. Macromolecules 2010, 43, 6853-6860. [CrossRef]

12. Bloksma, M.M.; Bakker, D.J.; Weber, C.; Hoogenboom, R.; Schubert, U.S. The effect of Hofmeister salts on the LCST transition of poly(2-oxazoline)s with varying hydrophilicity. Macromol. Rapid Commun. 2010, 31, 724-728. [CrossRef] [PubMed]

13. Tang, X.; Liang, X.; Gao, L.; Fan, X.; Zhou, Q. Water-soluble triply-responsive homopolymers of $\mathrm{N}, \mathrm{N}$-dimethylaminoethyl methacrylate with a terminal azobenzene moiety. J. Polym. Sci. Part A Polym. Chem. 2010, 48, 2564-2570. [CrossRef]

14. Plamper, F.A.; Ruppel, M.; Schmalz, A.; Borisov, O.; Ballauff, M.; Müller, A.H.E. Tuning the thermoresponsive properties of weak polyelectrolytes: Aqueous solutions of star-shaped and linear poly(N,N-dimethylaminoethyl methacrylate). Macromolecules 2007, 40, 8361-8366. [CrossRef]

15. Deng, J.J.; Shi, Y.; Jiang, W.D.; Peng, Y.F.; Lu, L.C.; Cai, Y.L. Facile synthesis and thermoresponsive behaviors of a well-defined pyrrolidone based hydrophilic polymer. Macromolecules 2008, 41, 3007-3014. [CrossRef]

16. Sun, J.; Peng, Y.F.; Chen, Y.; Liu, Y.; Deng, J.J.; Lu, L.C.; Cai, Y.L. Effect of molecular structure on thermoresponsive behaviors of pyrrolidone-based water-soluble polymers. Macromolecules 2010, 43, 4041-4049. [CrossRef]

17. Yan, N.; Zhang, J.; Yuan, Y.; Chen, G.T.; Dyson, P.J.; Li, Z.C.; Kou, Y. Thermoresponsive polymers based on poly(N-vinylpyrrolidone): Applications in nanoparticle catalysis. Chem. Commun. 2010, 46, 1631-1633. [CrossRef] [PubMed]

18. Yan, N.; Zhang, J.G.; Tong, Y.; Yao, S.; Xiao, C.; Li, Z.; Kou, Y. Solubility adjustable nanoparticles stabilized by a novel PVP based family: Synthesis, characterization and catalytic properties. Chem. Commun. 2009, 4423-4425. [CrossRef] [PubMed]

19. Trellenkamp, T.; Ritter, H. 3-ethylated N-vinyl-2-pyrrolidone with LCST properties in water. Macromol. Rapid Commun. 2009, 30, 1736-1740. [CrossRef] [PubMed]

20. Du, F.-S.; Huang, X.-N.; Chen, G.-T.; Lin, S.-S.; Liang, D.; Li, Z.-C. Aqueous solution properties of the acid-labile thermoresponsive poly(meth)acrylamides with pendent cyclic orthoester groups. Macromolecules 2010, 43, 2474-2483. [CrossRef]

21. Lambermont-Thijs, H.M.L.; Hoogenboom, R.; Fustin, C.-A.; Bomal-D’Haese, C.; Gohy, J.-F.; Schubert, U.S. Solubility behavior of amphiphilic block and random copolymers based on 2-ethyl-2-oxazoline and 2-nonyl-2-oxazoline in binary water-ethanol mixtures. J. Polym. Sci. Part A Polym. Chem. 2009, 47, 515-522. [CrossRef]

22. Hoogenboom, R.; Thijs, H.M.L.; Wouters, D.; Hoeppener, S.; Schubert, U.S. Tuning solution polymer properties by binary water-ethanolsolvent mixtures. Soft Matter 2008, 4, 103-107. [CrossRef]

23. Huang, X.; Du, F.; Ju, R.; Li, Z. Novel acid-labile, thermoresponsive poly(methacrylamide)s with pendentortho ester moieties. Macromol. Rapid Commun. 2007, 28, 597-603. [CrossRef]

24. Pakuro, N.; Yakimansky, A.; Chibirova, F.; Arest-Yakubovich, A. Thermo- and pH-sensitivity of aqueous poly(N-vinylpyrrolidone) solutions in the presence of organic acids. Polymer 2009, 50, 148-153. [CrossRef]

25. Braunecker, W.A.; Matyjaszewski, K. Controlled/living radical polymerization: Features, developments, and perspectives. Prog. Polym. Sci. 2007, 32, 93-146. [CrossRef]

26. Yokozawa, T.; Ogawa, M.; Sekino, A.; Sugi, R.; Yokoyama, A. Chain-growth polycondensation for well-defined aramide. Synthesis of unprecedented block copolymer containing aramide with low polydispersity. J. Am. Chem. Soc. 2002, 124, 15158-15159. [CrossRef] [PubMed]

27. Sugi, R.; Yokoyama, A.; Furuyama, T.; Uchiyama, M.; Yokozawa, T. Inductive effect-assisted chain-growth polycondensation. Synthetic development from para- to meta-substituted aromatic polyamides with low polydispersities. J. Am. Chem. Soc. 2005, 127, 10172-10173. [CrossRef] [PubMed] 
28. Huang, C.-F.; Chen, M.-J.; Lin, C.-H.; Chiang, Y.-W. Synthesis of well-defined poly( $N$-H benzamide-co- $N$-octyl benzamide)s and the study of their blends with nylon 6. Polymers 2017, 9, 172. [CrossRef]

29. Huang, C.-F.; Yokoyama, A.; Yokozawa, T. Synthesis of polybenzamide- $b$-polystyrene block copolymer via combination of chain-growth condensation polymerization and atom transfer radical polymerization. J. Polym. Sci. Part A Polym. Chem. 2010, 48, 2948-2954. [CrossRef]

30. Mecerreyes, D.; Jerome, R.; Dubois, P. Novel macromolecular architectures based on aliphatic polyesters: Relevance of the "coordination-insertion" ring-opening polymerization. Adv. Polym. Sci. 1999, 147, 1-59.

31. Hadjichristidis, N.; Pitsikalis, M.; Pispas, S.; Iatrou, H. Polymers with complex architecture by living anionic polymerization. Chem. Rev. 2001, 101, 3747-3792. [CrossRef] [PubMed]

32. Ito, S.; Goseki, R.; Ishizone, T.; Hirao, A. Synthesis of well-controlled graft polymers by living anionic polymerization towards exact graft polymers. Polym. Chem. 2014, 5, 5523-5534. [CrossRef]

33. Sawamoto, M. Modern cationic vinyl polymerization. Prog. Polym. Sci. 1991, 16, 111-172. [CrossRef]

34. Bielawski, C.W.; Grubbs, R.H. Living ring-opening metathesis polymerization. Prog. Polym. Sci. 2007, 32, 1-29. [CrossRef]

35. Huang, C.F.; Aimi, J.; Lai, K.Y. Synthesis of novel $\mu$-star copolymers with poly(N-octyl benzamide) and poly( $\varepsilon$-caprolactone) miktoarms through chain-growth condensation polymerization, styrenics-assisted atom transfer radical coupling, and ring-opening polymerization. Macromol. Rapid Commun. 2017, 38, 1600607. [CrossRef] [PubMed]

36. Huang, C.-F.; Ohta, Y.; Yokoyama, A.; Yokozawa, T. Efficient low-temperature atom transfer radical coupling and its application to synthesis of well-defined symmetrical polybenzamides. Macromolecules 2011, 44, 4140-4148. [CrossRef]

37. Hawker, C.J.; Bosman, A.W.; Harth, E. New polymer synthesis by nitroxide mediated living radical polymerizations. Chem. Rev. 2001, 101, 3661-3688. [CrossRef] [PubMed]

38. Chiefari, J.; Chong, Y.K.; Ercole, F.; Krstina, J.; Jeffery, J.; Le, T.P.T.; Mayadunne, R.T.A.; Meijs, G.F.; Moad, C.L.; Moad, G.; et al. Living free-radical polymerization by reversible addition-fragmentation chain transfer: The RAFT process. Macromolecules 1998, 31, 5559-5562. [CrossRef]

39. Kamigaito, M.; Ando, T.; Sawamoto, M. Metal-catalyzed living radical polymerization. Chem. Rev. 2001, 101, 3689-3745. [CrossRef] [PubMed]

40. Wang, J.S.; Matyjaszewski, K. Controlled living radical polymerization-atom-transfer radical polymerization in the presence of transition-metal complexes. J. Am. Chem. Soc. 1995, 117, 5614-5615. [CrossRef]

41. Yusa, S.; Yamago, S.; Sugahara, M.; Morikawa, S.; Yamamoto, T.; Morishima, Y. Thermo-responsive diblock copolymers of poly( $N$-isopropylacrylamide) and poly( $N$-vinyl-2-pyrroridone) synthesized via organotellurium-mediated controlled radical polymerization (TERP). Macromolecules 2007, 40, 5907-5915. [CrossRef]

42. Yamago, S.; Kayahara, E.; Kotani, M.; Ray, B.; Kwak, Y.; Goto, A.; Fukuda, T. Highly controlled living radical polymerization through dual activation of organobismuthines. Angew. Chem. Int. Ed. 2007, 46, 1304-1306. [CrossRef] [PubMed]

43. Yamago, S.; Ray, B.; Iida, K.; Yoshida, J.; Tada, T.; Yoshizawa, K.; Kwak, Y.; Goto, A.; Fukuda, T. Highly versatile organostibine mediators for living radical polymerization. J. Am. Chem. Soc. 2004, 126, 13908-13909. [CrossRef] [PubMed]

44. Gaynor, S.G.; Wang, J.S.; Matyjaszewski, K. Controlled radical polymerization by degenerative transfer-effect of the structure of the transfer agent. Macromolecules 1995, 28, 8051-8056. [CrossRef]

45. Teodorescu, M.; Matyjaszewski, K. Atom transfer radical polymerization of (meth)acrylamides. Macromolecules 1999, 32, 4826-4831. [CrossRef]

46. Matyjaszewski, K. Transition metal catalysis in controlled radical polymerization: Atom transfer radical polymerization. Chem. Eur. J. 1999, 5, 3095-3102. [CrossRef]

47. Matyjaszewski, K.; Patten, T.E.; Xia, J.H. Controlled/"living" radical polymerization. Kinetics of the homogeneous atom transfer radical polymerization of styrene. J. Am. Chem. Soc. 1997, 119, 674-680. [CrossRef]

48. Matyjaszewski, K.; Jo, S.M.; Paik, H.J.; Shipp, D.A. An investigation into the CuX/2,2'-bipyridine (X= Br or $\mathrm{Cl}$ ) mediated atom transfer radical polymerization of acrylonitrile. Macromolecules 1999, 32, 6431-6438. [CrossRef] 
49. Jakubowski, W.; Min, K.; Matyjaszewski, K. Activators regenerated by electron transfer for atom transfer radical polymerization of styrene. Macromolecules 2006, 39, 39-45. [CrossRef]

50. Jakubowski, W.; Matyjaszewski, K. Activators regenerated by electron transfer for atom-transfer radical polymerization of (meth)acrylates and related block copolymers. Angew. Chem. Int. Ed. 2006, 45, 4482-4486. [CrossRef] [PubMed]

51. Chen, G.T.; Wang, C.H.; Zhang, J.G.; Wang, Y.; Zhang, R.; Du, F.S.; Yan, N.; Kou, Y.A.; Li, Z.C. Toward functionalization of thermoresponsive poly(N-vinyl-2-pyrrolidone). Macromolecules 2010, 43, 9972-9981. [CrossRef]

52. Huang, C.-F.; Chang, F.-C. Comparison of hydrogen bonding interaction between PMMA/PMAA blends and PMMA-co-PMAA copolymers. Polymer 2003, 44, 2965-2974. [CrossRef]

53. Liu, H.Y.; Zhu, X.X. Lower critical solution temperatures of $N$-substituted acrylamide copolymers in aqueous solutions. Polymer 1999, 40, 6985-6990. [CrossRef]

54. Popkov, Y.M.; Nakhmanovich, B.I.; Chibirova, F.K.; Bune, E.V.; Arest-Yakubovich, A.A. Copolymerization in $N$-vinylcaprolactam- $N$-vinylpyrrolidone and $N, N$-diethylacrylamide- $N, N$-dimethylacrylamide systems: The effect of composition and spatial structure of copolymers on their thermal sensitivity. Polym. Sci. Ser. B 2007, 49, 155-158. [CrossRef]

(C) 2017 by the authors. Licensee MDPI, Basel, Switzerland. This article is an open access article distributed under the terms and conditions of the Creative Commons Attribution (CC BY) license (http://creativecommons.org/licenses/by/4.0/). 